\title{
Dinitrogen-Fixing Cyanobacteria in Microbial Mats of Two Shallow Coral Reef Ecosystems
}

\author{
Loic Charpy • Katarzyna A. Palinska • \\ Beatriz Casareto • Marie José Langlade • \\ Yoshimi Suzuki • Raeid M. M. Abed • Stjepko Golubic
}

Received: 11 June 2009/Accepted: 5 August 2009/Published online: 25 August 2009

(C) The Author(s) 2009. This article is published with open access at Springerlink.com

\begin{abstract}
Dinitrogen-fixing organisms in cyanobacterial mats were studied in two shallow coral reef ecosystems: La Reunion Island, southwestern Indian Ocean, Sesoko (Okinawa) Island, and northwestern Pacific Ocean. Rapidly expanding benthic miniblooms, frequently dominated by a
\end{abstract}

L. Charpy $\cdot$ M. J. Langlade

IRD, COM,

Rue de la Batterie des Lions,

13007 Marseille, France

\section{K. A. Palinska}

Geomicrobiology, ICBM, CvO University of Oldenburg, 26111 Oldenburg, Germany

\section{B. Casareto}

Laboratory of Aquatic Science and Consultant Co., LTD,

Meishin BLDG., Kamiikedai 1-14-1, Ota-ku,

Tokyo 145-0064, Japan

\section{Y. Suzuki}

Shizuoka University,

Oya 836 ,

Shizuoka 422-8529, Japan

R. M. M. Abed

Biology Department, College of Science,

Sultan Qaboos University,

PO Box 36, Al Khoud 123,

Muscat, Sultanate of Oman

\section{S. Golubic}

Biological Science Center, Boston University,

5 Cummington Str.,

Boston, MA 02215, USA

L. Charpy $(\bowtie)$

IRD, UR R167 Centre d'Océanologie de Marseille,

Traverse de la Batterie des Lions,

13007 Marseille, France

e-mail: loic.charpy@univmed.fr single cyanobacterial taxon, were identified by microscopy and molecular tools. In addition, nitrogenase activity by these blooms was measured in situ. Dinitrogen fixation and its contribution to mat primary production were calculated using ${ }^{15} \mathrm{~N}_{2}$ and ${ }^{13} \mathrm{C}$ methods. Dinitrogen-fixing cyanobacteria from mats in La Reunion and Sesoko showed few differences in taxonomic composition. Anabaena sp. among heterocystous and Hydrocoleum majus and Symploca hydnoides among nonheterocystous cyanobacteria occurred in microbial mats of both sites. Oscillatoria bonnemaisonii and Leptolyngbya spp. occurred only in $\mathrm{La}$ Reunion, whereas Hydrocoleum coccineum dominated in Sesoko. Other mats dominated by Hydrocoleum lyngbyaceum, Phormidium laysanense, and Trichocoleus tenerrimus occurred at lower frequencies. The 24-h nitrogenase activity, as measured by acetylene reduction, varied between 11 and 324 nmoles $\mathrm{C}_{2} \mathrm{H}_{2}$ reduced $\mu \mathrm{g}^{-1} \mathrm{Chl} a$. The highest values were achieved by heterocystous Anabaena sp. performed mostly during the day. Highest values for nonheterocystous cyanobacteria were achieved by $H$. coccineum mostly during the night. Daily nitrogen fixation varied from nine (Leptolyngbya) to 238 nmoles $\mathrm{N}_{2} \mu \mathrm{g}^{-1} \mathrm{Chl}$ day $^{-1}$ (H. coccineum). Primary production rates ranged from 1,321 (S. hydnoides) to 9,933 nmoles $\mathrm{C} \mu \mathrm{g}^{-1} \mathrm{Chl}$ day $^{-1}$ (H. coccineum). Dinitrogen fixation satisfied between $5 \%$ and $21 \%$ of the nitrogen required for primary production.

\section{Introduction}

Biological $\mathrm{N}_{2}$ fixation is a process unique to prokaryotes occurring commonly in freshwater and marine cyanobacteria. Although energetically demanding, this process provides the organisms with a particular advantage when 
growing under $\mathrm{N}$-limited conditions, which are most frequent in marine environments [17, 44]. The rates of nitrogen fixation, their relations to nitrogen concentration levels, and contribution to global oceans have been subject to extensive studies and reviews [e.g., [3, 8, 10, 29, 39]]. Due to oxygen sensitivity of the nitrogenase enzyme, the fixation of carbon and dinitrogen in an oxygen-producing organism needs to be separated either in space or in time [3, 39]. Spatial separation is achieved in heterocystous cyanobacteria which are able to fix dinitrogen during the day, contemporaneous with their energy generation. With some exceptions (e.g., Trichodesmium), nonheterocystous cyanobacteria temporally separate $\mathrm{N}_{2}$ fixation and oxygenic photosynthesis by fixing dinitrogen at night, using photosynthetic energy as ATP generated during the previous day [32].

Biological $\mathrm{N}_{2}$ fixation appears to make a major contribution to $\mathrm{N}$ supply in coral reef ecosystems, as it has been shown for the Eniwetok Atoll [48], the Great Barrier Reef [31], and for the lagoons of Tikehau Atoll [11] and New Caledonia [10]. Many studies of dinitrogen fixation have dealt with shallow areas of coral reefs $[8$, $16,31,42]$ including exposed communities of an atoll rim [12]. To our knowledge, none of these studies were performed on identified cyanobacterial populations that support microbial mats.

The main objective of our study is to identify the dominant taxa in cyanobacteria mats and determine their contribution to $\mathrm{N}_{2}$ fixation in shallow coral reef ecosystems.

For that, (1) we studied two shallow coral reef lagoons (Fig. 1): St. Gilles (La Reunion Island, Western Indian Ocean) and Sesoko (Okinawa Island, Japan, northern Pacific), (2) we combined phenotypic and molecular taxonomy to identify in situ dominant $\mathrm{N}_{2}$ fixers among benthic cyanobacteria, and (3) we used acetylene reduction, ${ }^{15} \mathrm{~N}$, and ${ }^{13} \mathrm{C}$ methods to measure their nitrogenase activity and carbon production.

\section{Materials and Methods}

Areas of Study

The present contribution is based on the field research performed in the framework of a Japan-French collaborative program at La Reunion Island (November, 2004 and February, 2007) and on Sesoko Island offshore of Okinawa (July, 2005 and October, 2006). In both sites, we used the facilities of marine stations laboratories.

La Reunion Island is located in the southwestern Indian Ocean $\left(21^{\circ} 7^{\prime} \mathrm{S}, 55^{\circ} 32^{\prime} \mathrm{E}\right) 700 \mathrm{~km}$ east of Madagascar. The climate is tropical with alternating rainy season from November to April (austral summer) and dry season from May to November. The tropical storm season is from November to April. The common reef geomorphology includes an outer slope, outer and inner reef flats, and a back reef. The fringing reefs are discontinuous and narrow (less than 550-m wide), and they cover only $7.3 \mathrm{~km}^{2}$. The reef flats are exposed at low water. Coral reef degradation has been monitored since 1985 by measuring physicochemical parameters and the state of benthic communities [14]. The area of our study (station A) is located at La Saline along the southwestern coast of Reunion Island (Fig. 2a). Five transects were made in November, 2004, and February, 2007, from the beach over back reef zone covered with detrital sediment to the inner reef flat, each about 300-m long. No sampling was done on the outer reef flat. The depth of the study area never exceeded $2 \mathrm{~m}$. The position of transects was selected so as to avoid nutrient enrichment due to submarine groundwater discharge, which is located north of the La Saline village $[13,15,38]$. These authors gave percentage coverage of live coral between $20 \%$ and $30 \%$ and macroalgal cover up to $40 \%$ on the reef flat.

Sesoko Island $\left(26^{\circ} 38^{\prime} \mathrm{N}, 27^{\circ} 51^{\prime} \mathrm{E}\right)$ is located off the NW coast of Okinawa in the Ryukyu Archipelago, southwestern Japan. The sea around the Ryukyus is under the influence of the warm Kuroshio Current and characterized by the

Figure 1 Geographic location of the studies of dinitrogen fixing cyanobacteria in La Reunion, Indian Ocean, SesokoOkinawa, and Pacific Ocean
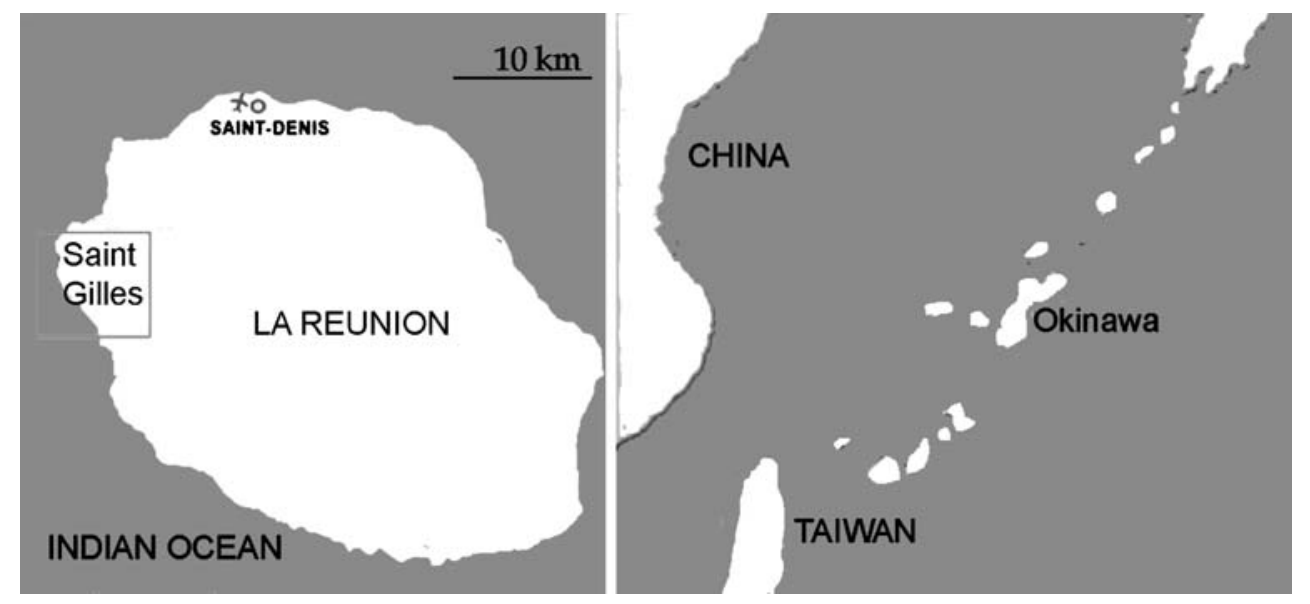
development of coral reefs from latitudes $24^{\circ}$ to $31^{\circ} \mathrm{N}$ marking their northernmost distribution. The climate is subtropical with a rainy season in early summer from May to the end of June. The tropical storm season is from July to October. Three sampling stations were selected in July, 2005, and October, 2006 (Fig. 2b). Station B (1- to 2-m depth) is located in a moat on the west coast of Sesoko Island behind a well-developed reef crest, located 150 $200 \mathrm{~m}$ from the shore [24]. Station C (1.5- to 2-m depth) is close to the bridge linking Sesoko to Okinawa, and Station D (2- to 3-m depth) is located next to the pier of Sesoko Station, Tropical Biosphere Research Center of the University of the Ryukyus.

\section{Environmental Parameters and Nutrients}

Temperature, salinity, and nutrient concentrations were routinely measured during field research operations. Triplicate subsamples of sea water for nutrient measurement were collected into clean acid-washed $100 \mathrm{~mL}$ polyethylene bottles and kept frozen. Nutrients were determined with an autoanalyzer (TRAACS-2000: BRAN+LUBE) according to Hansen and Koroleff [23]. Nitrate was determined by subtracting the values of nitrite from the values of nitrate + nitrite. The detection limits were $0.052 \mu \mathrm{M}$ for $\mathrm{NO}_{3}{ }^{-}+$ $\mathrm{NO}_{2}{ }^{-}, 0.01 \mu \mathrm{M}$ for $\mathrm{NO}_{2}{ }^{-}, 0.020 \mu \mathrm{M}$ for $\mathrm{NH}_{4}{ }^{+}$, and 0.020 $\mu \mathrm{M}$ for $\mathrm{PO}_{4}{ }^{3-}$. Reproducibility (margin of error) of nutrient analysis was $\pm 0.2 \%$ for $\mathrm{NO}_{3}{ }^{-}, \pm 0.5 \%$ for $\mathrm{NO}_{2}{ }^{-}, \pm 1.2 \%$ for $\mathrm{NH}_{4}{ }^{+}$, and $\pm 0.8 \%$ for $\mathrm{PO}_{4}^{-3}$.

\section{Distribution of Cyanobacterial Mats}

To estimate frequency and coverage of cyanobacterial mats in La Reunion lagoon, five transects, each ca 300-m long

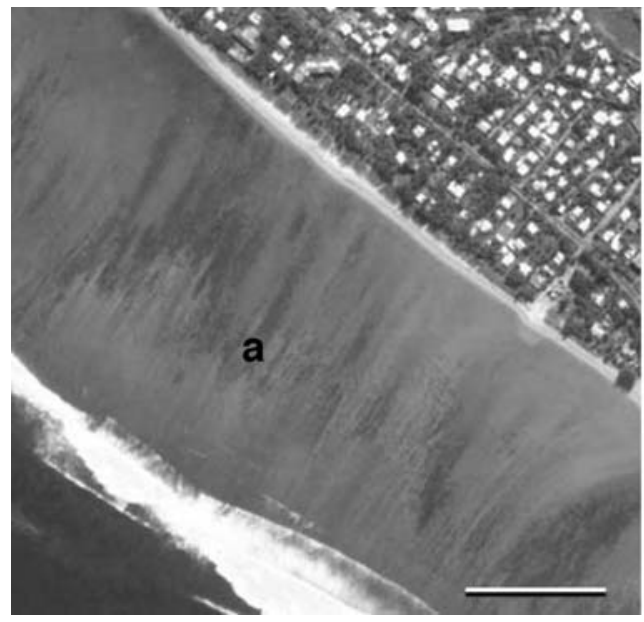

Figure 2 Areas of studies of cyanobacterial dinitrogen fixation in tropical lagoons. Lagoon on La Reunion Island at La Saline (station $A$ ) on the southwestern coast of the island. Stations $B, C$, and $D$ around from the beach to the reef flat were examined. The coverage of different morphotypes of cyanobacteria was estimated along each transect. This method of estimation could not be performed for Sesoko where mats were attached to small coral reef pinnacles with irregular distribution. Therefore, we could not calculate mean percent coverage of the mats along transects.

\section{Sampling}

Rapidly expanding local miniblooms of cyanobacteria, distinguished by their color and consistency, were documented by underwater photography and sampled using SCUBA diving. Live samples were microscopically analyzed immediately following collection. Samples found to be unicyanobacterial and in the expanding growth phase, were selected for further analyses. Samples were taken at the end of the day in order to optimize night nitrogenase activity, which depends on the light energy received during daylight [10]. Following sampling, one aliquot of the mat was preserved with formaldehyde (4\%) for later microscopic analysis; a second aliquot was stored in guanidine thiocyanate for DNA analysis [2], and a third aliquot was used for acetylene reduction assay in triplicate.

\section{Microscopic Analysis}

Microscopic analysis was carried out following collection to establish the composition of samples for analyses of carbon and nitrogen metabolism. Detailed microscopy and photomicrography, including morphometric evaluation, has been carried out subsequently on formaldehyde- and guanidinethiocyanate-fixed samples to aid morphotypic and genotypic characterization of the studied cyanobacteria. Zeiss RA and

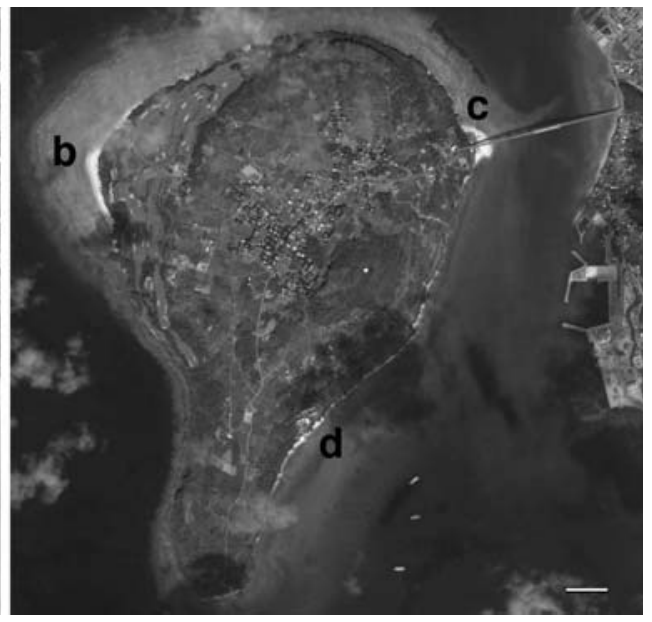

the Sesoko Island (Okinawa, Ryukyu Archipelago, southwestern Japan). Scale bars are 200-m long 
Universal Microscope (Carl Zeiss, Inc., Oberkochen, Germany) equipped with transmitted light and DIC illumination has been used with a digital photomicrographic camera attachment Moticam 2000 (Motic China, Co, Ltd.).

\section{Morphotypic Characterization}

The taxonomic identities of cyanobacteria under study were determined by polyphasic analysis in order to correlate their morphotypic properties (determined by S. Golubic) according to classifications by Geitler [20], Komárek and Anagnostidis [30] and Bergey's Manual [9] with sequences of 16S rRNA gene fragments (performed by K. Palinska). Measurements of cell dimensions were carried out on the basis of photomicrographs and in-scale camera-lucida projections. Measurements were recorded using SigmaScan software (Jandel Scientific, Sausalito, CA) and expressed as means \pm standard deviation of 20 to 50 measurements.

DNA Extraction, PCR Amplification, Sequencing and Phylogenetic Analysis

One milliliter of each population suspended in guanidine thiocyanate was added to $1 \mathrm{ml}$ of TESC $(10 \mathrm{mM}$ Tris, $1 \mathrm{mM}$ EDTA, $20 \mathrm{mM} \mathrm{NaCl}, 2 \%$ acetyltrimethylammonium bromide, $\mathrm{pH}$ 8.0). After addition of lysozyme (1\% final concentration), the samples were incubated at $37^{\circ} \mathrm{C}$ for $1 \mathrm{~h}$. After ten cycles of freeze (in liquid nitrogen) and thaw (at $\left.65^{\circ} \mathrm{C}\right), 5 \mu$ l proteinase $K(100 \mu \mathrm{g} / \mathrm{ml})$ and $90 \mu 110 \%$ sodium dodecyl sulfate was added, and the samples were incubated at $52{ }^{\circ} \mathrm{C}$ overnight. The samples were centrifuged in a microcentrifuge at $12,000 \times \mathrm{g}$ for $5 \mathrm{~min}$, and the supernatants were extracted twice with phenol, phenol/chloroform, and chloroform. The DNA was precipitated from the aqueous phase with 0.6 volumes of 2-propanol, washed with $70 \%$ ethanol, vacuum dried, and stored in $100 \mu \mathrm{L} \mathrm{TE}$ buffer (10 mM Tris, $1 \mathrm{mM}$ EDTA, $\mathrm{pH}$ 8.0).

Primers PLG1.1 and PLG2.1 described by Nadeau et al. [37] were used for amplification of partial 16S rRNA genes. The reaction volume was $100 \mu \mathrm{L}$ and contained: $1 \times$ REDTaq PCR Buffer, $200 \mu \mathrm{M}$ of each deoxynucleotide, $200 \mu \mathrm{g}$ BSA, $500 \mathrm{ng}$ of each oligonucleotide primer, $5 \mathrm{U}$ of RED Taq DNA polymerase (Sigma-Aldrich), and 1-10 $\mu \mathrm{L}$ of DNA extract. After an initial denaturation step (4 min at $\left.94{ }^{\circ} \mathrm{C}\right), 31$ incubation cycles followed, each consisting of $1 \mathrm{~min}$ at $94{ }^{\circ} \mathrm{C}, 1 \mathrm{~min}$ at $52{ }^{\circ} \mathrm{C}$, and $1.5 \mathrm{~min}(8 \mathrm{~min}$ at the last cycle) at $72{ }^{\circ} \mathrm{C}$. The presence of PCR products was detected by standard agarose gel electrophoresis and ethidium bromide staining. Amplification products were purified with the QIAquick PCR Purification Kit (Qiagen, Hilden, Germany).

DNA samples were directly sequenced in both directions by a commercial sequencing laboratory. Sequence similar- ities were calculated online with ClustalW ([25] at http:// www.ebi.ac.uk/clustalw/index.html). Sequence alignment and phylogeny of 16S rRNA fragments obtained from the populations were carried out using the ARB software version $07.12 .17 \mathrm{prv}$ and the official database (www.arbhome.de) from February 2005 for small subunit RNA sequences (ssu_jan04_corr_opt.arb). Additionally, cyanobacterial gene sequences available from the GenBank were imported and aligned in the database of the ARB software. These sequences were then aligned with the sequences in the ARB database using the alignment ARB tool. The alignment was corrected manually. The phylogenetic tree was calculated by maximum likelihood, based on long $16 \mathrm{~S}$ rRNA gene sequences. The sequences were inserted into the preestablished tree using the parsimony ARB tool while maintaining the overall tree topology without changes. The final tree was minimized for simplicity in presentation.

Incubation with Stable Isotopes and Acetylene Reduction

Immediately following sampling, the mats were placed in seawater collected at the same place and depth, enriched with $\mathrm{C}_{2} \mathrm{H}_{2}$ or ${ }^{15} \mathrm{~N}_{2}$ and $\mathrm{NaH}^{13} \mathrm{CO}_{3}$, and incubated in situ. Incubation started before the sunset and continued until early morning for dinitrogen fixation of nonheterocystous cyanobacteria. For heterocystous cyanobacteria, the incubation continued until the end of the following day [10].

\section{Nitrogenase Activity Measurements}

Nitrogenase activity was estimated by measuring the acetylene reduction rate (ARR). Short (1 h) and long-term $(12 \mathrm{~h})$ measurements were performed, using a single injection of acetylene [47]. Pieces of $1-\mathrm{cm}^{2}$ of mat were placed inside $175-\mathrm{mL}$ polycarbonate bottles fitted with a Teflon septum and filled with $125 \mathrm{~mL}$ of sea water from the sampling site. Experiments, in triplicate, were started by removing $5 \mathrm{~mL}$ of air above the sampled water and injecting the same volume of $\mathrm{C}_{2} \mathrm{H}_{2}$, followed by swirling for several minutes in the purpose of dissolving injected acetylene. $\mathrm{C}_{2} \mathrm{H}_{2}$ concentration measurements performed at the beginning of incubations demonstrated that $80 \%$ of the added $\mathrm{C}_{2} \mathrm{H}_{2}$ was dissolved in seawater. Light energy (PAR) was continuously recorded using a miniature light recorder (Alec Electronics Company). Four milliliters of gas mixture were taken using a vacuum tube at the end of the daylight and at the sunrise after swirling the sample for several minutes each time. Ethylene concentrations were measured using a gas chromatograph (Agilent $\mu \mathrm{GC}$ ) calibrated with commercial gas standards. Three replicates were measured from each incubation bottle. The dissolved ethylene concentration was calculated using the Bunsen gas solubility coefficient of 0.08 according to Breitbarth et al. [6] for a 
temperature of $28{ }^{\circ} \mathrm{C}$ and a salinity of 35 psu. ARR was calculated within each incubation period by subtracting $\mathrm{C}_{2} \mathrm{H}_{4}$ formed in the preceding period. The biomass of incubated benthic cyanobacteria was calculated from the chlorophyll $a$ content. At the end of incubation with $\mathrm{C}_{2} \mathrm{H}_{2}$, the mat was dried using Whatman filter paper and frozen for later spectrophotometric analysis of the La Reunion mats and for high performance liquid chromatography (HPLC) analysis of the Sesoko mats. The relative efficiency of nitrogenase activity was expressed as ARR per Chl $a$. Results are also presented as gross dinitrogen fixation rate calculated by using factor 4 in conversion from ARR [36].

\section{Net Dinitrogen Fixation and Primary Production}

Simultaneous dinitrogen fixation rate and dissolved inorganic carbon uptake measurements were carried out in duplicate (two incubation bottles) according to Slawyk et al. [43]. For each analysis, a $1-\mathrm{cm}^{2}$ piece of mat was placed inside a $175-\mathrm{ml}$ polycarbonate bottle fitted with a septum. In each bottle, ${ }^{13} \mathrm{C}$-labeled sodium bicarbonate $\left(\mathrm{NaH}^{13} \mathrm{CO}_{3}\right.$ :

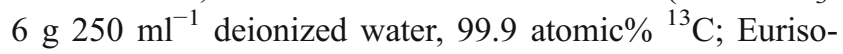
top) was added in order to obtain $11.5 \%$ final enrichment. Subsequently, $0.36 \mathrm{~mL}$ of ${ }^{15} \mathrm{~N}_{2}$ (99.8 atom \%, Shoko Co. Ltd., Tokyo, Japan) was added with a gas-tight syringe to obtain an enrichment of $6.8 \%$. Incubations were terminated by filtration under gentle pressure through a precombusted 47-mm diameter GF/F filter. The total wet weight of the incubated material was determined. An aliquot was dried at $60{ }^{\circ} \mathrm{C}$ for particulate organic carbon (POC), particulate organic nitrogen (PON), and isotope analysis, and another aliquot was frozen for HPLC analysis. Before analysis, filters were exposed to $\mathrm{HCl}$ fumes for $4 \mathrm{~h}$. Measurements of delta ${ }^{13} \mathrm{C}$, delta ${ }^{15} \mathrm{~N}$, and POC, PON were done using a mass spectrometer DELTA plus Advantage (Thermofinigan Co.) equipped with EA1110 for measurements of POC and PON. Primary production was calculated according to Hama et al. [22] using a time 0 enrichment of 1.089 and an initial DIC concentration of $2,400 \mu \mathrm{M}$. Dinitrogen fixation rate was calculated by isotope mass balance as described in Montoya et al. [34] using an $\mathrm{N}_{2}$ initial concentration of $386.16 \mu$ moles $\mathrm{L}^{-1}$ calculated for a temperature of $24{ }^{\circ} \mathrm{C}$ (laboratory temperature) and a salinity of $35 \mathrm{psu}$, assuming equilibrium with the overlying atmosphere.

\section{Chlorophyll Analysis}

Chlorophyll (Chl a) analyses were performed by spectrophotometry for La Reunion 2007 samples and by HPLC for La Reunion 2004 and Sesoko samples. Chlorophyll for spectrophotometric analysis was extracted in $10 \mathrm{ml}$ of $100 \%$ methanol, and absorption at $665 \mathrm{~nm}$ was recorded before and after acidification. Chl $a$ concentration was calculated using the extinction coefficients given by Porra et al. [41].

For HPLC analysis, the pigments were extracted with 95\% ethanol. HPLC was carried out with a model LC$10 \mathrm{AT}_{\mathrm{VP}}$ (Shimadzu, Kyoto, Japan) equipped with a column-temperature controller CTO-10AS $\mathrm{AP}_{\mathrm{VP}}$ (Shimadzu) using Waters Symmetry $C_{8}$ column $(150 \times 4.6 \mathrm{~mm}$; Waters, Milford, Massachusetts). Pigments were eluted at a flow rate of $1.0 \mathrm{~mL} / \mathrm{min}$ at $25{ }^{\circ} \mathrm{C}$ with a programmed binary gradient elution system. The solvents used were methanolacetonytryl-water (50:25:25) containing $62.5 \mathrm{mM}$ pyridine (solvent A) and methanol-acetonytryl-acetone (20:60:20; solvent B). Separation was performed with a gradient of ratio $(\mathrm{A}: \mathrm{B}, v / v)$ containing the break points of $0 \mathrm{~min}(100: 0$, $v / v), 22 \min (60: 40), 28 \min (5: 95), 38 \mathrm{~min}(5: 95)$, and $41 \mathrm{~min}$ (100:0). Separated pigments were detected spectrophotometrically with a photodiode array detector (Shimadzu SPD-M10AVP) measuring from 400 to $760 \mathrm{~nm}$. In this paper, we present only chlorophyll $a$ data.

\section{Results}

\section{The Environments Compared}

Temperature, salinity, and nutrient concentrations in the ambient waters were measured during our studies in both compared settings in La Reunion and Sesoko islands and are summarized in Table 1. The total dissolved inorganic nitrogen ( $\mathrm{DIN}=\mathrm{NO}_{3}{ }^{-}+\mathrm{NO}_{2}{ }^{-}+\mathrm{NH}_{4}{ }^{+}$) was highest in $\mathrm{La}$ Reunion in November $2004(1.71 \mu \mathrm{M})$ and lowest in Sesoko in station B in October $2006(0.20 \mu \mathrm{M})$. The high values in La Reunion were also reflected in the concentration of ammonia $(1 \mu \mathrm{M})$ and nitrate $(0.45 \mu \mathrm{M})$ indicating processes associated with eutrophication and coastal pollution. Reduced nitrogen compounds were always low in Sesoko. Dissolved $\mathrm{PO}_{4}{ }^{3-}$ concentrations were low $(<0.21$ $\mu \mathrm{M})$ in all stations at all times of study. Water temperature and salinity in both sites were similar during the times of these studies.

\section{Mat-Forming Cyanobacteria}

At both sites, benthic cyanobacteria occurred as scattered colonies which formed different types of organo-sedimentary structures on the lagoon floor. These structures differed in appearance and species composition. The species composition analyzed by light microscopy was correlated with the macroscopic appearance of the mat. The most common unicyanobacterial structures occurred as green mats, green tufts, dark colored mats, and globular orangecolored colonies. These were collected, analyzed, and used for determination of carbon and $\mathrm{N}_{2}$ fixation activities. 
Table 1 Temperature, salinity, mean \pm SE of light energy received between 11:00 and 16:00 at the incubation depth, and nutrient concentrations in La Reunion and Sesoko

\begin{tabular}{|c|c|c|c|c|c|c|c|c|}
\hline Place & Temperature $\left({ }^{\circ} \mathrm{C}\right)$ & Salinity & Light energy & $\mathrm{NO}_{3}^{-}$ & $\mathrm{NO}_{2}^{-}$ & $\mathrm{NH}_{4}^{+}$ & DIN & $\mathrm{PO}_{4}{ }^{-3}$ \\
\hline Reunion, Nov. 2004 & 28.5 & 32.3 & $1928 \pm 854$ & 0.45 & 0.26 & 1.00 & 1.71 & 0.10 \\
\hline Reunion, Feb. 2007 & 26.3 & 35.1 & $1696 \pm 724$ & 0.32 & 0.13 & 0.10 & 0.55 & 0.21 \\
\hline Sesoko, Jul. 2005 & 29.4 & 34.3 & $2104 \pm 497$ & 0.66 & 0.04 & 0.10 & 0.80 & 0.07 \\
\hline Sesoko, St B, Oct. 2006 & 27.6 & 34.5 & $1816 \pm 598$ & 0.09 & 0.001 & 0.11 & 0.20 & 0.14 \\
\hline Sesoko, St D, Oct. 2006 & 27.3 & 34.6 & $1442 \pm 392$ & 0.28 & 0.04 & 0.17 & 0.49 & 0.04 \\
\hline
\end{tabular}

Values presented are mean $\pm \mathrm{SE}$ of light energy $\left(\mu \mathrm{mol} \mathrm{cm} \mathrm{c}^{-2} \mathrm{~s}^{-1}\right)$ and nutrient concentrations $(\mu \mathrm{M})$

Percent coverage of cyanobacterial mats on bottom substrates observed at La Reunion in February 2007, are presented in Table 2. Microbial mats were much more abundant in February during the summer rainy season than in November at the end of the dry season. During the study, the bottom consisted $75.4 \%$ of sand, $22.5 \%$ of coral, and $2.1 \%$ of macroalgae. Microbial mats occurred mainly over sand and to lesser extent on other substrates. They were dominated by Leptolyngbya, Oscillatoria, Anabaena, and Hydrocoleum. In Sesoko Island, the nature of the bottom consisted of areas with sand, corals, and macroalgae, but the proportions were not measured. In July, 2005, sandy bottom at the station $\mathrm{C}$ was covered by mats of Hydrocoleum spp. Other microbial mats produced by Phormidium, Anabaena, Symploca, Oscillatoria, and Leptolyngbya, were exclusively attached to hard substrates. Common species in both sites were: Anabaena sp., Symploca hydnoides, and Hydrocoleum majus.

The field aspects of dominant microbial mat-forming cyanobacteria are shown in the left columns of Figs. 3 and 4 with their corresponding photomicrographic illustrations in the right column of these figures. The positions of the obtained 16S rRNA gene sequences (412-552 bp) of these organisms are shown in a reconstructed phylogenetic tree of cyanobacteria in Fig. 5.

Anabaena sp.-LC1 is the closest morphotypic identity of this common heterocystous benthic cyanobacterium that forms bright blue-green colonies with upright oriented filaments waving in the current (Fig. 3a). Its trichomes were comprised of torulose cells $7.65 \pm 0.37-\mu \mathrm{m}$ wide, slightly shorter or longer than wide; heterocysts were slightly larger

Table 2 Percent of coverage $\pm \mathrm{SE}$ of cyanobacteria mats in $\mathrm{La}$ Reunion in February 2007

\begin{tabular}{lc}
\hline Organism & Percent coverage \\
\hline Anabaena sp. LC1 & $0.07 \pm 0.04$ \\
Leptolyngbya sp. LC2 & $3.09 \pm 1.30$ \\
H. majus RU2007 & $0.01 \pm 0.01$ \\
O. bonnemaisonii LC4 & $1.50 \pm 0.42$ \\
\hline
\end{tabular}

and longer then vegetative cells (Fig. 3b). The 16S rRNA gene sequence (accession no. GQ251521) similarity to GenBank listings of Anabaena sp. SSM-00 and Anabaena sp. LMECYA 185 show $98 \%$ and $96 \%$, respectively (Fig. 5). The organism was present at low density in several transects in the lagoon of La Reunion in November, 2004, and February, 2007, close to the inner reef flat. Anabaena sp. was observed in Sesoko in July, 2005 at the station B but not in October, 2006.

S. hydnoides Kützing ex Gomont formed characteristic dark brown cusp-shaped colonies (Fig. 3c) comprised of bundled, sheathed filaments externally, often in a leaf-like arrangement. Trichomes were $7.14 \pm 1.32-\mu \mathrm{m}$ wide, not constricted at the cross walls but with slight constriction toward the tips. Apical cells were rounded without calyptra (Fig. 3d). Sheaths were firm, birefringent in polarized light with periodic convex closures (Fig. 3d, insert). The $16 \mathrm{~S}$ rRNA gene sequence (accession no. GQ251525) matched with a 94\% similarity with GenBank listings of Symploca PCC8002 and S. hydnoides TK22 population described at Tikehau Lagoon [1] (Fig. 5). The colonies of S. hydnoides were observed in La Reunion lagoon attached to Acropora close to the inner reef flat in 2004 and in 2007 as well as in Sesoko at station B in July, 2005.

Oscillatoria bonnemaisonii Crouan ex Gomont identified large unsheathed cyanobacteria forming loose olivegreen mats, which dominated the floor of the La Reunion lagoon in February, 2007 (Fig. 3e). Trichomes were unsheathed, motile, and flexuous with tendency of forming lose helical undulations (Fig. 3f). Cells were slightly constricted at the cross walls, $32.8 \pm 2.28-\mu \mathrm{m}$ wide, and very short $(3-6 \mu \mathrm{m})$. The $16 \mathrm{~S}$ rRNA gene sequence (accession no. GQ251524) matched the GenBank sequences listed as Oscillatoria spongeliae isolate 513bg and Oscillatoria corallinae with similarities of $96 \%$ and $95 \%$, respectively (Fig. 5). The organism was observed only during one occasion in La Reunion but then as a dominant cyanobacterium that covered $1.5 \pm 0.4 \%$ of the seafloor along the measured transect.

H. majus Holden formed distinct bush-like colonies blue to violet in color, comprised of upward diverging filaments 
Figure 3 Cyanobacterial colonies and mats in the lagoons (left column) with corresponding microscopic aspects of the organisms (right column). a Field view of Anabaena colony with filaments waving in the current, Sesoko station B, scale bar is 5-cm long. b Trichomes of Anabaena sp.: note the heterocyst in the center, scale bar is 20- $\mu \mathrm{m}$ long. c Compact colony of $S$. hydnoides, Sesoko station B: note upright leaf-like filament arrangement, scale bar is 5-cm long. d Filament and empty sheaths of $S$. hydnoides. Insert: sheath with closures; scale bar is $20-\mu \mathrm{m}$ long. e Loose Oscillatoria mats over sand floor in the lagoon, $\mathrm{La}$ Reunion station A; scale bar is 50-cm long. f Intertwined trichomes of Oscillatoria bonnemaisoni; scale bar is $20-\mu \mathrm{m}$ long
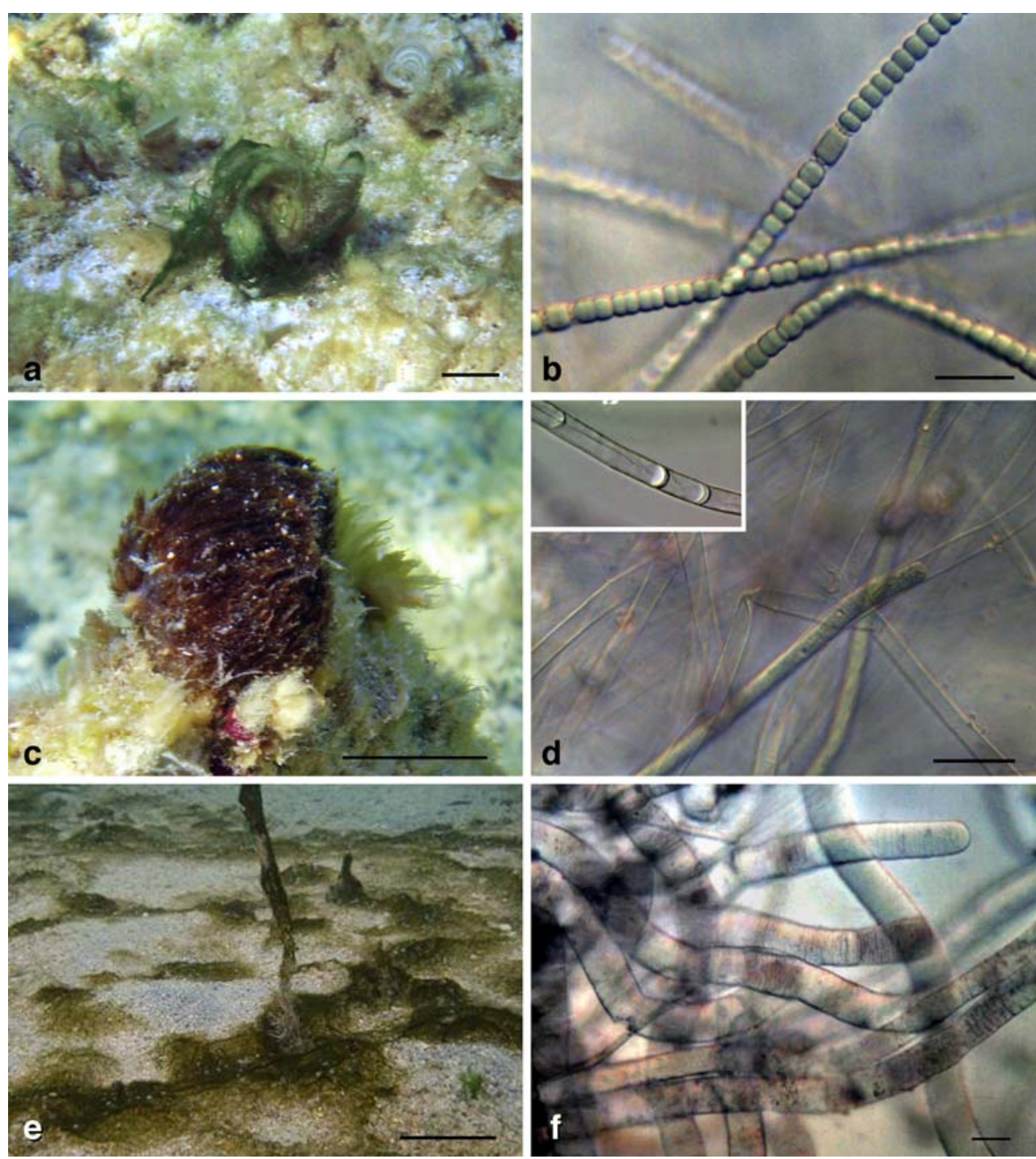

(Fig. 4a). Filaments contained one to three trichomes surrounded by a thick, layered, and colorless sheath. Trichomes were straight and rigid, 29.05 $\pm 1.25-\mu \mathrm{m}$ wide, cells $5.84 \pm 1.43$ long, not constricted at the crosswalls, abruptly narrowing at the tips, and ending with a distinct apical cell covered with calyptra (Fig. 4b). Cells were dark purple in color due to high concentrations of phycocyanin and phycoerythrin. The 16S rRNA gene sequence (accession no. GQ251521) showed closest similarity at $96 \%$ to a sequence listed in GenBank as Hydrocoleum lyngbyaceum HBC7 (Fig. 5). Colonies of H. majus RU2007 were observed sporadically on Acropora in La Reunion in February 2007 as well as a minor component in $H$. coccineum mats of Sesoko.

Other Hydrocoleum morphotypes corresponding to species $H$. coccineum Gomont, $H$. glutinosum Gomont, and $H$. lyngbyaceum Kützing were observed in 2006 in Sesoko, station B, forming brown-colored mats. The mats covering large areas of the sandy bottom at station $\mathrm{C}$ at 2-m depth in
July, 2005, were dominated by $H$. coccineum. They occurred intermixed with small (4- $\mu$ m wide) representatives of the genus Oscillatoria and Leptolyngbya. H. glutinosum was present at the same time only on the outer rim of the reef, close to station B at 6-m depth. The sequences of these organisms were not obtained.

Phormidium laysanense Lemmermann formed colonies of varying shape and consistency, from loose veils to upright extending coatings, bright red to pink in color (Fig. 4c). Filaments contained single trichomes within a thin, firm sheath. Cells were $5.8 \pm 0.44-\mu \mathrm{m}$ wide and $7.83 \pm$ $1.72-\mu \mathrm{m}$ long. End cell gradually attenuated covered at the tip by a conical or hemispherical calyptra (Fig. 4d). $P$. laysanense was observed in Sesoko at station D in 2005 and 2006, at shallow depths $(2-5 \mathrm{~m})$ inside caves of reef pinnacles.

Leptolyngbya spp. represents nonheterocystous cyanobacteria with narrow trichomes, which formed coatings over sand and massive corals (Fig. 4e). The trichomes 
Figure 4 Cyanobacterial mats and mat-forming cyanobacteria from La Reunion and Sesoko. a Bush-like colony of H. majus showing upward diverging multitrichomous filaments detectable by plain eye view; La Reunion station A; scale bar is 1-cm long. b Trichomes of $H$. majus: note the distinct calyptrate apical cell; scale bar is 20$\mu \mathrm{m}$ long. c Orange color mats of $P$. laysanense coating coral rubble, Sesoko station B; scale bar is $20-\mathrm{cm}$ long. d Filaments of $P$. laysanense in growth position arranged parallel to each other: note the capitate and calyptrate apical cell and thin firm sheaths containing single trichomes; scale bar is $20-\mu \mathrm{m}$ long. e Mat of Leptolyngbya sp. coating a dead coral. Note the pinnaclelike outgrowth and extensions of the mat, La Reunion station A; scale bar is $50-\mathrm{cm}$ long. $\mathbf{f}$ Leptolyngbya $\mathrm{sp}$. filaments containing single trichomes inside thin firm sheaths. Cells with distinct crosswalls, close to 1 $\mu \mathrm{m}$ wide and slightly shorter or longer than wide; scale bar is $20-\mu \mathrm{m}$ long
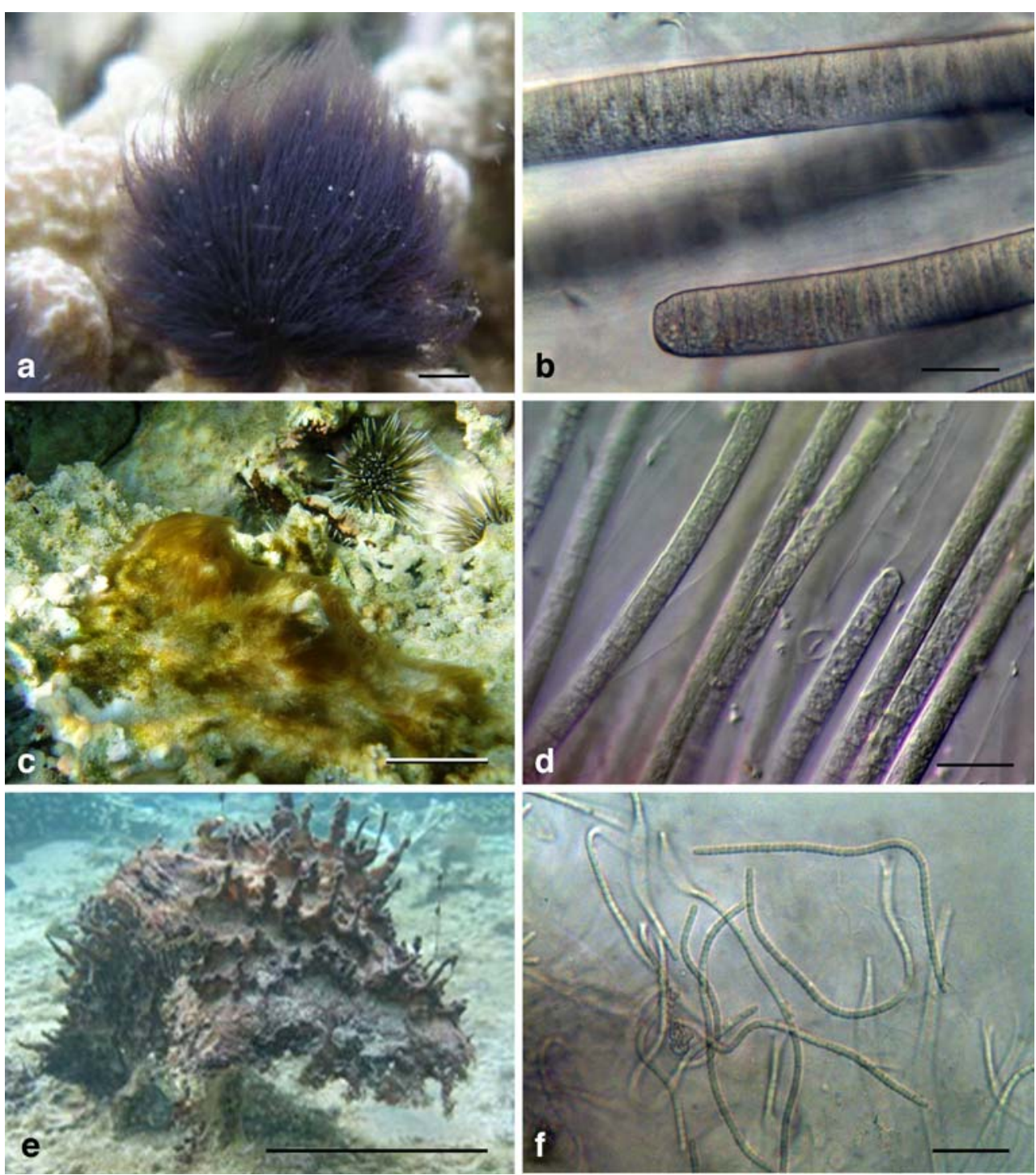

were sheathed, comprised of cells $1-1.5$ - $\mu \mathrm{m}$ wide, slightly shorter or longer than wide and with distinct cross walls, frequently gliding and abandoning the sheaths (Fig. 4f). Two populations from La Reunion that have been sequenced (accession nos. Gq251522 and GQ251523) cluster closely together (Fig. 5) but had different pigmentation. In La Reunion, in February, 2007, these mats were the second-most common mat formations (next to $O$. bonnemaisonii). Along the measured transect in station A, Leptolyngbya mats covered on the average $3.1 \pm 1.3 \%$ of the sediment. In the parts of transect between 30 and $80 \mathrm{~m}$ from the beach, they covered $5 \%$ to $10 \%$. At the end of the day, the mats become partially uplifted by the bubbles of oxygen they produced. Other mat-forming cyanobacteria were observed as minor constituents of benthos. Flat, brown-red mats consisting of Trichocoleus tenerrimus were found in 2005 and 2006 at low densities at stations B and D.
Nitrogenase Activity

Nitrogenase activities of dominant heterocystous and nonheterocystous benthic cyanobacteria measured by ethylene production and expressed as ARR as well as $\mathrm{N}_{2}$ fixation rates (NF) are presented in Table 3 as means \pm standard error of triplicate measurements.

In both sites, Anabaena sp.-LC1 reduced $\mathrm{C}_{2} \mathrm{H}_{2}$ mainly during the daytime. In $\mathrm{La}$ Reunion the mean $\mathrm{ARR}$ value was $11.3 \pm 1.2$ nmoles $\mathrm{C}_{2} \mathrm{H}_{2} \mu \mathrm{g}^{-1} \mathrm{Chl} a \mathrm{~h}^{-1}$ during the day and $0.45 \pm 0.05$ nmoles $\mathrm{C}_{2} \mathrm{H}_{2} \mu \mathrm{g}^{-1} \mathrm{Chl} a \mathrm{~h}^{-1}$ during the night. In Sesoko Island, Anabaena sp. reduced $\mathrm{C}_{2} \mathrm{H}_{2}$ with a mean ARR value of $32.3 \pm 4.2$ nmoles $\mu \mathrm{g}^{-1} \mathrm{Chl} a \mathrm{~h}^{-1}$ during the daytime and between 0 and 8 nmoles $\mathrm{C}_{2} \mathrm{H}_{2} \mu \mathrm{g}^{-1}$ Chl $a \mathrm{~h}^{-1}$ (ten times lower but variable) during the night.

In contrast to heterocystous cyanobacteria, the mats dominated by Hydrocoleum glutinosum and H. coccineum, analyzed in Sesoko, showed nitrogenase activity only during 


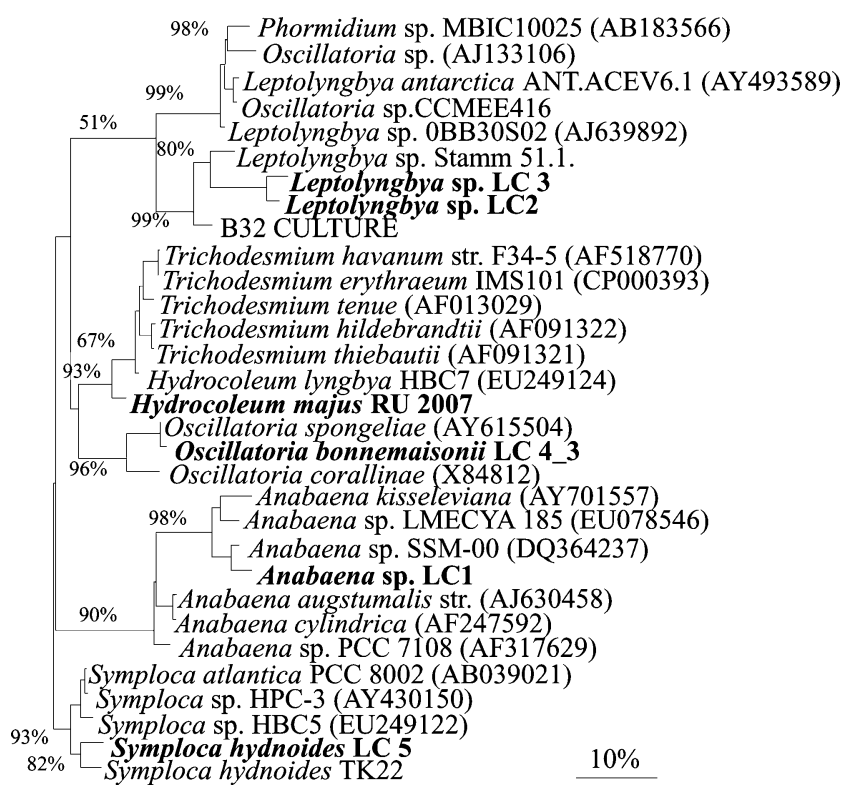

Figure $516 \mathrm{~S}$ rRNA-based phylogenetic reconstruction showing the affiliation of sequences retrieved from six cyanobacterial populations originating from La Reunion lagoon. Accession numbers are indicated in parentheses. The scale bar indicates $10 \%$ sequence divergence. Data from in this study are shown in bold

the night. Their mean ARR were $14.5 \pm 3.1$ and $12.5 \pm$ 4.8 nmoles $\mu \mathrm{g}^{-1} \mathrm{Chl} a \mathrm{~h}^{-1}$, respectively. Mats dominated by $H$. lyngbyaceum showed in Sesoko, nitrogenase activity both during the night and during the day after. In La Reunion, H. majus mat was measured only one time at night and showed very low activity: $1.07 \pm 0.24$ nmoles $\mathrm{C}_{2} \mathrm{H}_{2} \mu \mathrm{g}^{-1} \mathrm{Chl} a \mathrm{~h}^{-1}$.
Mats dominated by nonheterocystous Leptolyngbya spp. (LC2, LC3), O. bonnemaisonii (LC4), and S. hydnoides (LC5) in La Reunion showed nitrogenase activity both during the night and the daylight time. Their mean night ARR were $2.70 \pm 0.19,1.15 \pm 0.21$, and 0.48 nmoles $\mathrm{C}_{2} \mathrm{H}_{2}$ $\mu^{-1} \mathrm{Chl} a \mathrm{~h}^{-1}$, respectively. Their mean daylight ARR were $1.62 \pm 0.14$ for Leptolyngbya sp., $1.64 \pm 0.47$ for $O$. bonnemaisonii, and 0.48 nmoles $\mathrm{C}_{2} \mathrm{H}_{2} \mu \mathrm{g}^{-1} \mathrm{Chl} a \mathrm{~h}^{-1}$ for $S$. hydnoides.

In Sesoko, P. laysanense, and T. tenerrimus showed nitrogenase activity during the night and the daytime. Their mean night ARR were $6.8 \pm 0.8,1.24 \pm 0.11$, and $2.12 \pm$ 0.75 nmoles $\mu \mathrm{g}^{-1} \mathrm{Chl} a \mathrm{~h}^{-1}$, respectively. Their mean daylight ARR was $7.53 \pm 0.12,0.98 \pm 0.14$, and $2.18 \pm$ 1.06 nmoles $\mu \mathrm{g}^{-1} \mathrm{Chl} a \mathrm{~h}^{-1}$, respectively. S. hydnoides did not show nitrogenase activity.

Daily gross $\mathrm{N}_{2}$ fixation rates (Table 3 ), calculated using a theoretical value of four as discussed in Charpy et al. [10], showed the highest $\mathrm{N}_{2}$ fixation rates of $101 \pm 17$ nmoles $\mathrm{N}_{2}$ $\mu \mathrm{g}^{-1} \mathrm{Chl} \mathrm{day}{ }^{-1}$ for Anabaena sp. of Sesoko. The rates for the same species in La Reunion were significantly lower: $36 \pm 4$ nmoles $\mathrm{N}_{2} \mu \mathrm{g}^{-1} \mathrm{Chl}$ day $^{-1}$. In Sesoko, H. coccineum, and Hydrocoleum glutinosum daily $\mathrm{N}_{2}$ fixation rates were high, $77 \pm 33$ and $54 \pm 16$ nmoles, $\mathrm{N}_{2} \mu \mathrm{g}^{-1} \mathrm{Chl}$ day $^{-1}$, respectively.

\section{Isotopic Measurements of $\mathrm{N}_{2}$ Fixation and Primary Production}

Dinitrogen fixation rates and primary production rates based on measurements of ${ }^{15} \mathrm{~N}_{2}$ and ${ }^{13} \mathrm{C}$ incorporation,

Table 3 Mean $\pm \mathrm{SE}$ of acetylene reduction rate during night and daylight and dinitrogen fixation calculated from $A R R$ and the ratio $\mathrm{C}_{2} \mathrm{H}_{2}: \mathrm{N}_{2}=4$

\begin{tabular}{|c|c|c|c|c|c|c|}
\hline Organism & $\mathrm{ARR}_{\mathrm{ni}}$ & $\mathrm{ARR}_{\mathrm{dl}}$ & $\mathrm{ARR}_{24 \mathrm{~h}}$ & $\mathrm{NF}_{\mathrm{ni}}$ & $\mathrm{NF}_{\mathrm{dl}}$ & $\mathrm{NF}_{24 \mathrm{~h}}$ \\
\hline \multicolumn{7}{|l|}{ La Reunion } \\
\hline Anabaena sp. & $0.45 \pm 0.05$ & $11.33 \pm 1.17$ & $142.7 \pm 16.1$ & $1.9 \pm 0.4$ & $34.4 \pm 3.9$ & $35.7 \pm 4.0$ \\
\hline S. hydnoides & 0.48 & 0.48 & 11.5 & 1.32 & 1.55 & 2.9 \\
\hline Leptolyngbya sp. & $2.70 \pm 0.19$ & $1.62 \pm 0.14$ & $50.8 \pm 5.8$ & $7.4 \pm 0.5$ & $5.3 \pm 0.4$ & $12.7 \pm 0.8$ \\
\hline H. majus & $1.15 \pm 0.21$ & ND & ND & $3.2 \pm 0.6$ & ND & ND \\
\hline O. bonnemaisonii & $1.07 \pm 0.24$ & $1.64 \pm 0.47$ & $34.9 \pm 8.0$ & $2.6 \pm 0.7$ & $5.3 \pm 1.5$ & $8.7 \pm 2.0$ \\
\hline \multicolumn{7}{|l|}{ Sesoko } \\
\hline Anabaena sp. & $0-8$ & $32.29 \pm 4.24$ & $324.1 \pm 69.2$ & $13.2 \pm 6.1$ & $96.9 \pm 12.0$ & $101.0 \pm 17.3$ \\
\hline S. hydnoides & 0 & ND & 0 & 0 & ND & ND \\
\hline Leptolyngbya sp. & $5.99 \pm 3.36$ & $0.18 \pm 0.20$ & $97.9 \pm 107.0$ & $24.5 \pm 26.7$ & 0 & $24.5 \pm 26.7$ \\
\hline H. coccineum & $12.48 \pm 4.80$ & 0 & $306.8 \pm 130.3$ & $76.7 \pm 32.6$ & 0 & $76.7 \pm 32.6$ \\
\hline Hydrocoleum glutinosum & $14.54 \pm 3.09$ & $0.06 \pm 0.03$ & $216.6 \pm 65.0$ & $35.7 \pm 10.7$ & $0.2 \pm 0.1$ & $54.2 \pm 16.2$ \\
\hline H. lyngbyaceum & $6.8 \pm 0.8$ & $7.53 \pm 0.12$ & $171.1 \pm 18.4$ & $20.4 \pm 4.8$ & $22.6 \pm 0.7$ & $42.8 \pm 4.6$ \\
\hline P. laysanense & $1.24 \pm 0.11$ & $0.98 \pm 0.14$ & $26.7 \pm 1.6$ & $3.71 \pm 0.98$ & $2.94 \pm 1.27$ & $6.7 \pm 0.4$ \\
\hline T. tenerrimus & $2.12 \pm 0.75$ & $2.18 \pm 1.06$ & 51.6 & $6.37 \pm 2.08$ & $6.54 \pm 1.05$ & $12.9 \pm 6.8$ \\
\hline
\end{tabular}

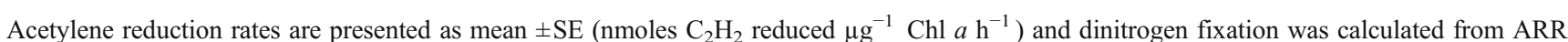
and the ratio $\mathrm{C}_{2} \mathrm{H}_{2}: \mathrm{N}_{2}=4$ (nmoles $\mathrm{N}_{2}$ fixed $\mu \mathrm{g}^{-1} \mathrm{Chl} a$ ). ARR acetylene reduction rate, ni night, $d l$ daylight, and $N F$ dinitrogen fixation 
were performed in three mats in La Reunion, dominated by Anabaena sp., S. hydnoides, and Leptolyngbya sp. and one mat in Sesoko Island dominated by H. coccineum. The results are summarized in Table 4. Daily nitrogen fixation varied from nine (Leptolyngbya) to 238 nmoles $\mathrm{N}_{2} \mu \mathrm{g}^{-1}$ $\mathrm{Chl}$ day $^{-1}$ (H. coccineum). The primary production rates ranged from 1,321 (S. hydnoides) to 9,933 nmoles ${\mathrm{C} \mu \mathrm{g}^{-1}}^{-1}$ Chl day ${ }^{-1}$ (H. coccineum).

\section{Discussion}

Benthic Cyanobacteria in Coral Reef Ecosystems

Mats collected in La Reunion and Sesoko represent a variety of cyanobacterial morphotypes that are active in $\mathrm{N}_{2}$ fixation. Populations of cyanobacteria dominated by representatives of the form-genera Anabaena, Oscillatoria, Phormidium, Hydrocoleum, Symploca, and Leptolyngbya were present in both geographically remote ecosystems surveyed in the present study. The following dominant morphospecies occurred in both sites: Anabaena sp., $P$. laysanense, H. majus, and S. hydnoides.

The heterocystous cyanobacteria form a monophyletic group [9, 21, 26]. However, for the members of this group, especially genera: Anabaena, Nodularia, Aphanizomenon, and Cylindrospermopsis; descriptions of morphotypes are often insufficient to discriminate between them and so are descriptions of strain histories. Genetically closely related strains or strains of similar morphotype often carry different specific or even generic epithets.

The genus Anabaena Bory describes a large number of taxa in freshwater plankton including toxic bloom-forming species. Morphologically similar marine taxa are usually classified under the genus Nodularia [4, 5]. Diversity and ecological features of Anabaena and Nodularia from marine benthic habitats are less well known than those from planktonic habitats [46]. The study of Lyra et al. [33] showed that benthic cyanobacteria of the genus Nodularia from the Baltic Sea are nontoxic, without gas vacuoles, able to glide and are genetically more diverse than planktonic Nodularia. Marine Anabaena strains have already been reported from the Mexican Gulf coast of Texas as fastgrowing $\mathrm{N}$-fixing organisms well adapted to warm shallow marine environments $[35,45]$.

The 16S rRNA gene sequence of Anabaena sp.-LC1 identified morphologically in samples from La Reunion shows similarity to other heterocystous cyanobacteria, identified as Anabaena (98\%) and Cylindrospermopsis raciborskii (95\%) but only $94 \%$ to Nodularia harveyana. Such low level of similarity indicates that the organisms we encountered on the reef of La Reunion were not yet represented in GenBank.

O. bonnemaisonii is a large, well-characterized filamentous cyanobacterium reported from marine habitats worldwide [30]. However, the closest match with published sequences identifies a relation to a listing under the name $O$. spongeliae. The basis for the listing identification is not known; however, the original description of that morphotype, Oscillatoria spongeliae Schulze 1879, is different from our strain and not even typical for the form-genus Oscillatoria. That taxon has been classified by different authors as Phormidium and Borzia, in addition to Oscillatoria [30].

H. majus, the largest in the genus, was observed in mats at La Reunion, as dominant species, and at Sesoko, as subdominant. In the latter case, mats were dominated by $H$. coccineum, $H$. glutinosum and $H$. lyngbyaceum. Species of Hydrocoleum (Blennothrix in Komárek and Anagnostidis [30]) were reported to be very abundant in Tikehau Atoll lagoon [1], Kabira reef sediments, Ishigaki Island, SW Japan [29], and in the SW lagoon of New Caledonia [10]. They are considered to be among the most common matforming cyanobacteria in tropical oceans with the genetic potential to fix $\mathrm{N}_{2}$, closely related to the species of the planktonic genus Trichodesmium [2].

Leptolyngbya sp. was the most abundant cyanobacterium at La Reunion in February 2007, covering 3.1 $1.3 \%$ of

Table 4 Mean \pm SE of dinitrogen fixation calculated from ${ }^{15} \mathrm{~N}$ experiments during the night and $24 \mathrm{~h}, 24 \mathrm{~h}$ primary production, C:N ratio of mats, and the contribution of $\mathrm{NF}$ to the total $\mathrm{N}$ requirement for $\mathrm{PP}$

\begin{tabular}{|c|c|c|c|c|c|c|}
\hline Organism & ${ }^{15} \mathrm{NF}_{\mathrm{ni}}$ & ${ }^{15} \mathrm{NF}_{24 \mathrm{~h}}$ & $\mathrm{C}_{2} \mathrm{H}_{2}: \mathrm{N}_{2}$ & PP (\%) & $\mathrm{C}: \mathrm{N}$ & Percentage $(\%)$ \\
\hline \multicolumn{7}{|l|}{ La Reunion } \\
\hline Anabaena sp. LC1 & 0.7 & 27.8 & 5.1 & $3,291 \pm 630$ & $7.4 \pm 0.2$ & 6.3 \\
\hline S. hydnoides LC5 & $8.2 \pm 4.1$ & $10.0 \pm 4.3$ & 1.2 & $1,321 \pm 431$ & $11.3 \pm 3.6$ & 8.6 \\
\hline Leptolyngbya sp. LC2 & $8.7 \pm 2.6$ & $8.8 \pm 2.6$ & 5.8 & $2,709 \pm 825$ & $15.3 \pm 0.9$ & 5.0 \\
\hline \multicolumn{7}{|l|}{ Sesoko } \\
\hline H. coccineum & 288.1 & 238.5 & 1.1 & 9,933 & $8.8 \pm 0.3$ & 21.1 \\
\hline
\end{tabular}

Mean \pm SE of dinitrogen fixation was calculated from ${ }^{15} \mathrm{~N}$ experiments. Primary production was measured in nmoles $\mathrm{C} \mu \mathrm{g}^{-1} \mathrm{Chl} a$; $\mathrm{C}: \mathrm{N}$ ratio $(a t: a t)$ of mats. ${ }^{15} N F^{15} \mathrm{~N}$ experiments, $n i$ night, $P P$ primary production 
transect over sandy bottom. However, the morphogenus Leptolyngbya is polyphyletic and includes a number of unrelated organisms of simple morphology [9].

\section{Dinitrogen Fixation}

The acetylene reduction method does not measure $\mathrm{N}_{2}$ fixation rates directly; it needs to be calibrated by calculating the $\mathrm{C}_{2} \mathrm{H}_{2}: \mathrm{N}_{2}$ ratio (mol:mol). Multiple studies have shown the conversion ratio of ethylene to $\mathrm{N}$ to be highly variable. In coral reef ecosystems, values for benthic mats range from 1.8 to 4.8 in Tuamotu Atoll lagoon [11] and from 0.3 to 4.7 in Kabira reef [29]. In Sesoko and La Reunion, the ratio ranged between 1.1 and 5.8 with an average of 3.3. This value was close to the conversion ratio of 4:1 appropriate for quantification of gross $\mathrm{N}_{2}$ fixation as measured by $\mathrm{C}_{2} \mathrm{H}_{2}$ reduction $[19,27,36]$.

Paerl et al. [40] observed a decrease in $\mathrm{N}_{2}$ fixation after an enrichment of $100 \mu \mathrm{M} \mathrm{NO}_{3}$. This enrichment is 60 , the maximum DIN observed in La Reunion waters. Joye and Lee [28] observed a substantial (80\%) and instantaneous reduction in $\mathrm{N}_{2}$ fixation rates after the addition of inorganic nitrogen $\left(2 \mathrm{mM} \mathrm{NO}_{3}\right)$. However, these authors reported that in some cases, the addition of inorganic nitrogen had no effect on $\mathrm{N}_{2}$ fixation. The enrichment used here is 1,000 times the maximum DIN concentration in overlying waters. Camacho and de Wit [7] observed that a $400 \mu \mathrm{M} \mathrm{NH} \mathrm{NO}_{3}$ addition had no direct effect onto $\mathrm{N}_{2}$ fixation rate. All these enrichments are largely higher than DIN concentrations in La Reunion and Sesoko waters.

Dinitrogen fixation in oligotrophic waters of La Reunion in 2004 was observed to continue when the surrounding waters contained $1.71 \mu \mathrm{M}$ nitrate concentration. It is possible that, in such cases, the availability of dissolved nitrogen in the microenvironment immediately surrounding the microorganism was exhausted and its replacement rate deficient. Thus, the concentration of a nutrient measured in the macroenvironment does not necessarily correspond to its availability to the microorganisms.
Dark $\mathrm{N}_{2}$ fixation by heterocystous cyanobacteria and light $\mathrm{N}_{2}$ fixation by nonheterocystous cyanobacteria are frequently reported in the literature. Gallon et al. [19] observed that the planktonic heterocystous Nodularia can fix $\mathrm{N}_{2}$ during the night. They consider that cells can sustain $\mathrm{N}_{2}$ fixation, at least to a limited extent, by metabolic processes that operate in the dark. The nonheterocystous cyanobacterium, Symploca PCC 8002, is capable of fixing $\mathrm{N}_{2}$ aerobically in light. The synthesis of nitrogenase takes place in a minor proportion of consecutively arranged cells [18].

Data on $\mathrm{N}_{2}$ fixation for coral reef mats are relatively rare and are mainly expressed per square meter of substrate rather than per unit of $\mathrm{Chl} a$. Our results related to unit of biomass (Table 5 ) can be directly compared with the data set of Kayanne et al. [29] and Charpy et al. [10]. ARR in Anabaena sp., $H$. lyngbyaceum, $H$. cantharidosmum, and H. coccineum were in the same order of magnitude in New Caledonia, Sesoko, and La Reunion but higher than the ARR value reported for $H$. cantharidosmum in Kabira reef.

Dinitrogen Fixation as an Input to the Primary Production in Microbial Mats

To estimate the contribution of dinitrogen fixation to the total nitrogen requirement for the primary production (PP) of four mats, we used the value of $\mathrm{PP}$ and $\mathrm{C}: \mathrm{N}$ ratio from the Table 4. Based on these values, $\mathrm{N}_{2}$ fixation represents between $5 \%$ (Leptolyngbya sp.) to $21 \%$ (H. coccineum) of that required for primary production. This contribution is close to the percentage (19\%) given by Charpy et al. [10] for sediment of New Caledonia lagoon and nearly ten times higher than the percentage (2\%) given by Charpy-Roubaud et al. [11] for Tikehau atoll lagoon.

\section{Lagoonal Dinitrogen Fixation}

The whole lagoonal mat $\mathrm{N}_{2}$ fixation could be estimated only for La Reunion in February 2007, when we had a

Table 5 Comparison of acetylene reduction rates in coral reef environments

\begin{tabular}{llll}
\hline Mats (dominant cyanobacteria) & Place & ARR (nmol $\left.\mathrm{C}_{2} \mathrm{H}_{2} \mu \mathrm{g}^{-1} \mathrm{Chl} a \mathrm{~d}^{-1}\right)$ & Reference \\
\hline Nodularia harveyana & New Caledonia & $205 \pm 12$ & Charpy et al. [10] \\
Anabaena sp. & Sesoko & $324 \pm 69$ & This study \\
Anabaena sp. & La Reunion & $143 \pm 16$ & This study \\
H. lyngbyaceum & New Caledonia & $123 \pm 25$ & Charpy et al. [10] \\
& Sesoko & $171 \pm 18$ & This study \\
Hydrocoleum cantharidosmum & Kabira reef & 2.4 & Kayanne et al. [29] \\
& New Caledonia (St. MBO) & $122 \pm 20$ & Charpy et al. [10] \\
H. coccineum & Sesoko & $307 \pm 130$ & This study \\
\hline
\end{tabular}

$A R R$ acetylene reduction rates 
good estimation of the mat coverage. Using the lagoon bottom percent coverage of the mats and the dinitrogen fixation rate per square centimeter ${ }^{2}$ of mats, we obtained a mat $\mathrm{N}_{2}$ fixation of $2.16 \mathrm{mg} \mathrm{N}$ fixed per square meter of lagoon. This value is inside the large range of dinitrogen fixation rates reported by Charpy-Roubaud et al. [11] for various coral reef ecosystems.

Dinitrogen fixation measurements of microbial mats combined with polyphasic studies of cyanobacterial diversity proved advantageous by achieving identification of the principal phototrophic contributors of benthic diazotrophy. The heterocystous genus Anabaena and the nonheterocystous genus Hydrocoleum appear to be important benthic dinitrogen fixers in the two investigated coral reef ecosystems. Their $\mathrm{N}_{2}$ fixation rates are in the same order of magnitude and both heterocystous and nonheterocystous cyanobacteria are capable of light and dark $\mathrm{N}_{2}$ fixation.

Mat diversity and their role in $\mathrm{N}_{2}$ fixation in the two geographically distant ecosystems under study appear to be similar. Mats in both ecosystems were also comparable in sea water characteristics, such as light, temperature, salinity and nutrients.

The results suggest global importance of benthic cyanobacterial dinitrogen fixation and call for further investigations of microbial mats in coral reef ecosystems. Our approach in identifying natural populations involved in dinitrogen fixation are required to assess the contribution of benthic cyanobacteria to dinitrogen fixation in relation to their distribution and biodiversity.

Acknowledgments This work was supported by grants from the Ocean Development Sub-Committee of France-Japan S\&T Cooperation, Mitsubishi cooperation, the Ministry of Education, Science, Sport, and Culture of Japan and from IRD. Hanse Wissenschaftskolleg, Delmenhorst and Alexander-von-Humboldt Foundation, Bad Godesberg, Germany supported collaborative research on cyanobacterial diversity. We thank A. Couté for his help in Sesoko cyanobacteria identification, the laboratory ECOMAR from the University of La Reunion, and the Sesoko Marine Station for their help in the field. We wish also to thank Tatjana Schwetzler for the help in molecular analysis.

Open Access This article is distributed under the terms of the Creative Commons Attribution Noncommercial License which permits any noncommercial use, distribution, and reproduction in any medium, provided the original author(s) and source are credited.

\section{References}

1. Abed RMM, Golubic S, Garcia Pichel F, Camoin GF, Sprachta S (2003) Characterization of microbialite-forming cyanobacteria in a tropical lagoon: Tikehau Atoll, Tuamotu, French Polynesia. J Phycol 39:862-873

2. Abed RMM, Palinska KA, Camoin G, Golubic S (2006) Common evolutionary origin of planktonic and benthic nitrogen-fixing oscillatoriacean cyanobacteria from tropical oceans. FEMS Microbiol Lett 260:171-177
3. Berman-Frank I, Lundgren P, Falkowski P (2003) Nitrogen fixation and photosynthetic oxygen evolution in cyanobacteria. Research in Microbiology 154:157-164

4. Bolch CJS, Orr PT, Jones GJ, Blackburn SI (1999) Genetic, morphological, and toxicological variation among globally distributed strains of Nodularia (Cyanobacteria). J Phycol 35:339-355

5. Bornet E, Flahault C (1886, 1887, 1888) Révision des Nostocacées hétérocystées. Ann Sci Nat Bot Sér 7, 3:323-381, 4:343-373, 5:51-129, 7:177-262

6. Breitbarth E, Mills MM, Friedrichs G, LaRoche J (2004) The Bunsen gas solubility coefficient of ethylene as a function of temperature and salinity and its importance for nitrogen fixation assays. Limnol Oceanogr Methods 2:282-288

7. Camacho A, de Wit R (2003) Effect of nitrogen and phosphorus additions on a benthic microbial mat from a hypersaline lake. Aquat Microb Ecol 32:261-273

8. Capone DG, Dunham SE, Horrigan SG, Duguay LE (1992) Microbial nitrogen transformations in unconsolidated coral reef sediments. Mar Ecol Prog Ser 80:75-88

9. Castenholz RW, Rippka R, Herdman M, Wilmotte A (2001) Subsection III. (Formerly Oscillatoriales Elenkin 1934). In: Garrity G (ed) Bergey's manual of systematic bacteriology, 2nd edn. Springer-Verlag, New York, pp 539-562

10. Charpy L, Alliod R, Rodier M, Golubic S (2007) Benthic nitrogen fixation in the SW New Caledonia lagoon. Aquat Microb Ecol 47:73-81

11. Charpy-Roubaud C, Charpy L, Larkum AWD (2001) Atmospheric dinitrogen fixation by benthic communities of Tikehau Lagoon (Tuamotu Archipelago, French Polynesia) and its contribution to benthic primary production. Mar Biol 139:991-997

12. Charpy-Roubaud C, Larkum A (2005) Dinitrogen fixation by exposed communities on the rim of Tikehau atoll (Tuamotu Archipelago, French Polynesia). Coral Reefs 24:622-628

13. Chazottes V, Le Campion-Alsumard T, Peyrot-Clausade M, Cuet $P$ (2002) The effects of eutrophication-related alterations to coral reef communities on agents and rates of bioerosion (Reunion Island, Indian Ocean). Coral reefs 21:375-390

14. Conand C (2002) Marine ecology of La Reunion: an overview of recent research. AMBIO 31:602-605

15. Cuet P, Naim O, Faure G, Conan JY (1988) Nutrient-rich groundwater impact on benthic communities of La Saline fringing reef (Reunion Island, Indian Ocean): preliminary results. Proc Int Coral Reefs Symp 2:207-212

16. D'Elia CF, Wiebe WJ (1990) Biogeochemical nutrient cycles in coral-reef ecosystems. In: Dubinski Z (ed) Coral reefs. Elsevier Science, Amsterdam, pp 49-74

17. Dugdale RC (1967) Nutrient limitation in the sea: dynamics, identification and significance. Limnol Oceanogr 12:685-695

18. Fredriksson C, Malin G, Siddiqui PJA, Bergman B (1998) Aerobic nitrogen fixation is confined to a subset of cells in the non-heterocystous cyanobacterium Symploca PCC 8002. New Phytol 140:531-538

19. Gallon JR, Evans AM, Jones DA, Albertano P, Congestri R, Bergman B, Gundersen K, Orcutt KM (2002) Maximum rates of $\mathrm{N}_{2}$ fixation and primary production are out of phase in a developing cyanobacterial bloom in the Baltic Sea. Limnol Oceanogr 47:1514-1521

20. Geitler L (1932) Cyanophyceae. Kryptogamenflora von Deutschland, Österreich und der Schweiz. Akademische Verlagsgesellschaft, Leipzig Reprinted 1971, Johnson, New York, London, pp 1-1196

21. Giovannoni SJ, Turner S, Olsen GJ, Barns S, Lane DJ, Pace NR (1988) Evolutionary relationships among cyanobacteria and green chloroplasts. J Bacteriol 170:3584-3592

22. Hama T, Hama J, Handa $N(1993){ }^{13} \mathrm{C}$ tracer methodology in microbial ecology with special reference to primary production 
processes in aquatic environments. In: Jones JG (ed) Advances in microbial ecology, vol 13. Plenum Press, New York, pp 39-83

23. Hansen K, Koroleff F (1999) Detemination of nutrients. In: Grasshoff K, Kremling K, Ehrhardt M (eds) Methods of seawater analysis. Wiley, Weiheim, pp 159-228

24. Hata H, Nishihira M, Kamura S (2002) Effects of habitat-conditioning by the damselfish Stegastes nigricans (Lacepede) on the community structure of benthic algae. J Exp Mar Biol Ecol 280:95-116

25. Higgins D, Thompson J, Gibson T, Thompson JD, Higgins DG, Gibson TJ (1994) CLUSTAL W: improving the sensitivity of progressive multiple sequence alignment through sequence weighting, position-specific gap penalties and weight matrix choice. Nucleic Acids Res 22:4673-4680

26. Iteman I, Rippka R, de Marsac NT, Herdman M (2002) rDNA analyses of planktonic heterocystous cyanobacteria, including members of the genera Anabaenopsis and Cyanospira. Microbiology 148:481-496

27. Jensen BB, Cox RP (1983) Direct measurements of steady-state kinetics of cyanobacterial $\mathrm{N}_{2}$ uptake by membrane-leak mass spectrometry and comparisons between nitrogen fixation and acetylene reduction. Appl Environ Microbiol 45:1331-1337

28. Joye SB, Lee RY (2004) Benthic microbial mats: important sources of fixed nitrogen and carbon to the Twin Cays, Belize ecosystem. Atoll Res Bull 528:1-24

29. Kayanne H, Hirota M, Yamamuro M, Koike I (2005) Nitrogen fixation of filamentous cyanobacteria in a coral reef measured using three different methods. Coral Reefs 24:197-200

30. Komárek J, Anagnostidis K (2005) Cyanoprokaryota. Part 2 Oscillatoriales. In: Büdel B, Gärtner G, Krienitz 1, Schagerl M (eds) Süsswasserflora von Mitteleuropa, vol 19(2). Elsevier Spectrum, Heidelberg, pp 1-759

31. Larkum AWD, Kennedy IR, Muller WJ (1988) Nitrogen fixation on a coral reef. Mar Biol 98:143-155

32. Lundgren P, Bauer K, Lugomela C, Söderbäck E, Bergman B (2003) Reevaluation of the nitrogen fixation behavior in the marine non-heterocystous cyanobacterium Lyngbya majuscula. J Phycol 39:310-314

33. Lyra C, Laamanen M, Lehtimaki JM, Surakka A, Sivonen K (2005) Benthic cyanobacteria of the genus Nodularia are nontoxic, without gas vacuoles, able to glide and genetically more diverse than planktonic Nodularia. Int J Syst Evol Microbiol 55 (Part 2):555-568

34. Montoya J, Voss M, Kahler P, Capone D (1996) A simple, highprecision, high-sensitivity tracer assay for $\mathrm{N}_{2}$ fixation. Appl Environ Microbiol 62:986-993
35. Moreno J, Vargas MA, Rodríguez H, Rivas J, Guerrero MG (2003) Outdoor cultivation of a nitrogen-fixing marine cyanobacterium, Anabaena sp. ATCC 33047. Biomol Engin 20:191-197

36. Mulholland MR, Bronk DA, Capone DG (2004) Dinitrogen fixation and release of ammonium and dissolved organic nitrogen by Trichodesmium IMS101. Aquat Microb Ecol 37:85-94

37. Nadeau T-L, Milbrandt EC, Castenholz RW (2001) Evolutionary relationships of cultivated Antarctic oscillatorians (cyanobacteria). J Phycol 37:650-654

38. Naim O (1993) Seasonal responses of a fringing reef community to eutrophication (Reunion Island, western Indian Ocean). Mar Ecol Prog Ser 99:137-151

39. Paerl HW (1990) Physiological ecology and regulation of $\mathrm{N}_{2}$ fixation in natural waters. Adv. Microb Ecol 11:305-344

40. Paerl HW, Joye SB, Fitzpatrick M (1993) Evaluation of nutrient limitation of $\mathrm{CO}_{2}$ and $\mathrm{N}_{2}$ fixation in marine microbial mats. Mar Ecol Prog Ser 101:297-306

41. Porra RJ, Thompson WA, Kriedmann PE (1989) Determination of accurate extinction coefficients and simultaneous equations for assaying chlorophylls $a$ and $b$ extracted with four different solvents: verification of the concentrations of chlorophyll standards by atomic absorption spectroscopy. Biochem Biophys Acta 975:384-394

42. Shashar N, Feldstein T, Cohen Y, Loya Y (1994) Nitrogen fixation (acetylene reduction) on a coral reef. Coral Reefs 13:171-174

43 Slawyk G, Collos Y, Auclair JC (1977) The use of ${ }^{13} \mathrm{C}$ and ${ }^{15} \mathrm{~N}$ isotopes for the simultaneous measurement of carbon and nitrogen rates in marine phytoplankton. Limnol Oceanogr 22:925-932

44 Staal M, Meysman FJR, Stal LJ (2001) Temperature excludes $\mathrm{N}_{2-}$ fixing heterocystous cyanobacteria in the tropical oceans. Nature 425:505-507

45. Stacey G, van Baalen C, Tabita R (1977) Isolation and characterization of a marine Anabaena sp. capable of rapid growth on molecular nitrogen. Arch Microbiol 114:197-201

46. Stal LJ, Albertano P, Bergman B, Kv B, Gallon JR, Hayes PK, Sivonen K, Walsby AE (2003) BASIC: Baltic Sea cyanobacteria. An investigation of the structure and dynamics of water blooms of cyanobacteria in the Baltic Sea-responses to a changing environment. Cont Shelf Res 23:1695-1714

47. Stewart WDP, Fitzgerald GP, Burris RH (1967) In situ studies on $\mathrm{N}_{2}$ fixation using the acetylene reduction technique. Biochemistry 58:2071-2078

48. Webb KL, DuPaul WD, Wiebe W, Sottile W, Johannes RE (1975) Enewetak (Eniwetok) atoll: aspects of the nitrogen cycle on a coral reef. Limnol Oceanogr 20:198-210 